\title{
MEASURING SLEEP LITERACY IN HEALTHCARE STUDENTS: AN OBSERVATIONAL STUDY
}

\author{
D Tavares \\ Escola Superior de Saúde, Politécnico do Porto \\ Centro de Investigação em Reabilitação (CIR), Escola Superior de Saúde \\ Politécnico do Porto \\ M Amorim \\ Escola Superior de Saúde, Politécnico do Porto \\ Centro de Investigação em Saúde e Ambiente (CISA), Escola Superior de Saúde \\ Politécnico do Porto \\ manuela.amorim@ess.ipp.pt \\ L Leite \\ Escola Superior de Saúde, Politécnico do Porto \\ R Cerveira Lima \\ Escola Superior de Saúde, Politécnico do Porto \\ Centro de Astrofísica e Ciências do Espaço da Universidade de Coimbra
}

Recepción Artículo: 22 octubre 2021

Admisión Evaluación: 22 octubre 2021

Informe Evaluador 1: 23 octubre 2021

Informe Evaluador 2: 24 octubre 2021

Aprobación Publicación: 24 octubre 2021

\section{ABSTRACT}

In recent years, research has focused on the various potentialities and functions associated with so-called restorative sleep, in the general population and not only in individuals with more serious pathologies. Thus, sleep hygiene rules have been defined in order to allow, in an accessible way, everyone to actively contribute to their quality of sleep. Health students play a key role as active agents in primary care, health promotion and disease prevention. But to assume this role, as a living example and educator, they often need to increase their health literacy, which must go far beyond specific knowledge. With this observational study, we aimed to assess the actual knowledge of higher education students in courses in the area of health (School of Health of the Polytechnic of Porto), through an online questionnaire with some factual statements on this topic. It is expected that the data collected will allow the identification of misconceptions and misconceptions about the area of sleep, thus revealing which lines of intervention still need to be invested in literacy in this area.

Keywords: literacy; sleep; higher education students; health

\section{RESUMEN}

Medición de la alfabetización del sueño en estudiantes de atención médica: un estudio observacional. En los últimos años, la investigación se ha centrado en las diversas potencialidades y funciones 
asociadas al Ilamado sueño reparador, en la población general y no solo en individuos con patologías más graves. Así, se definieron unas reglas de higiene del sueño, con el fin de permitir, de forma accesible, que cada uno pueda contribuir activamente a su calidad de sueño. Los estudiantes de salud juegan un papel clave como agentes activos en la atención primaria, la promoción de la salud y la prevención de enfermedades. Pero para asumir este papel, como ejemplo vivo y educador, a menudo necesitan aumentar su alfabetización en salud, que debe ir mucho más allá de los conocimientos específicos. Con este estudio observacional, se pretendió evaluar el conocimiento real de los estudiantes de educación superior en cursos en el área de la salud (Escuela de Salud de la Politécnica de Oporto), a través de un cuestionario en línea con algunas declaraciones sobre hechos sobre este tema. Se espera que los datos recolectados permitan identificar conceptos y conocimientos erróneos sobre el área del sueño, revelando así qué líneas de intervención aún quedan por invertir en materia de alfabetización en esta área.

Palabras clave: alfabetización; sueño; estudiantes de educación superior; salud

\section{INTRODUCTION}

Sleep-related problems have been increasingly seen as a public health issue. These days, there is social pressure for multitasking, shortening the time and quality of sleep (1). There are several sleep problems with different triggers such as physiological, emotional, behavioural or habits/lifestyle issues.

Non-restorative sleep or chronic sleep deprivation due to acquired habits, unregulated schedules or sleep disorders such as insomnia, obstructive sleep apnea or neurological diseases can lead to the onset of diseases or health risk situations $(2,3)$. Currently, the cognitive ability deficit associated with sleep deficit is increasingly recognized as an important issue of public health and safety, perception, memory and executive functions (4).

Many sleep problems can be resolved by changing habits or lifestyles. The knowledge of sleep rules/hygiene can substantially improve people's quality of life and their performance in their daily activities. Despite increasing knowledge of the importance of sleep on health, there is still no campaign to promote adequate sleep habits (1).

The National Assessment of Adult Literacy (NAAL) defines health literacy as follows: communicative/interactive health literacy takes functional health literacy and adds the ability to obtain new information, understand its meaning in context, and use it in a variety of situations (5). Thus, determining the degree of health literacy about sleep and finding the weak points in knowledge, will allow the intervention in the community of measures to improve the quality of life through an enhancement in the quality of sleep.

\section{GOAL}

Assess the level of literacy in the sleep area of healthcare students from the ESSIP.Porto.

\section{METHODOLOGY}

Observational, descriptive and cross-sectional study, which consisted on an online questionnaire to measure the sleep literacy of the participants, carried out in a single moment in time. Participants were recruited through social media, through a publication about the study and their request for collaboration.

The inclusion criterion was being of legal age and being a student at ESSIP.Porto. The questionnaire was made available via Google forms, in the publication itself made on social networks, without identifying data.

\section{RESULTS}

Of the total number of participants $(\mathrm{n}=48)$ the majority are female $(\mathrm{N}=39 ; 81.3 \%)$ and from 3 ESS degree courses, namely Clinical Physiology $(n=27 ; 56.3 \%)$, Environmental Health $(n=18 ; 37.5 \%)$, and Orthoptics $(n=3$; $6.3 \%)$.

Regarding the quality of sleep, most participants consider that sleeping 7-8 hours/day is a reference value for the individual to feel good ( $n=43 ; 89.6 \%$ ), and knows that if they sleep in a very short period of time cannot be recovered with long hours of sleep afterwards ( $n=45 ; 93.8 \%$ ). It should be noted that more than half of the sample considers that the change in time does not interfere with sleep quality $(n=31 ; 64.6 \%)$. 
$100 \%$ of participants consider that either the "increased stress hormones" can "interfere with the quality of sleep" or that "relaxation activities can induce drowsiness/sleep". Regarding the use of electronic devices at night, most participants know its real effect ( $n=42 ; 87.5 \%)$, as well as alcohol $(n=42 ; 87.5 \%)$.

Most participants know that melatonin induces sleep and is regulated by light $(n=47 ; 97.9 \%)$, that in coastal cities in Portugal there is light pollution $(n=44,91.7 \%)$ and that the process of memory consolidation occurs during sleep $(n=41,85.4 \%)$. A small percentage considered that a shift worker after some time starts to have an adjusted circadian rhythm without affecting their daily sleep ( $n=11,22.9 \%)$.

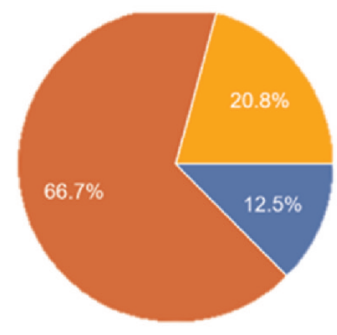

Figure 1 - participants' perception of the effect of the blue light filter on electronic devices being fictitious (most know that this statement is false and only a small minority say they do not know 20.8\%).

\section{CONCLUSION}

In this observational study, it was found that sleep literacy is high, probably because we are dealing with participants with basic and specific training in the area of health sciences, although there are still residual values of uncertainties and misconceptions that can be improved. In the future, it would be important to compare the results obtained in this population (with a more representative sample), with a population from different areas of knowledge, such as basic sciences, engineering, management and arts.

\section{BIBLIOGRAPHIC REFERENCES}

1. Irish LA, Kline CE, Gunn HE, Buysse DJ, Hall MH. The role of sleep hygiene in promoting public health: A review of empirical evidence. Sleep Med Rev. 2015; 22:23-36.

2. Hanson JA, Huecker MR. Sleep Deprivation. StatPearls. Treasure Island (FL). 2021.

3. Tobaldini E, Costantino G, Solbiati M, Cogliati C, Kara T, Nobili L, et al. Sleep, sleep deprivation, autonomic nervous system and cardiovascular diseases. Neurosci Biobehav Rev. 2017; 74(Pt B):321-9.

4. Killgore WD. Effects of sleep deprivation on cognition. Prog Brain Res. 2010; 185:105-29.

5. Hackney JE, Weaver TE, Pack Al. Health literacy and sleep disorders: a review. Sleep Med Rev. 2008;12(2):14351. 
